\title{
Indonesian Law Development on Housing Collateral
}

\author{
J Andy Hartanto \\ Lecturer, Faculty of Law, \\ Narotama University Surabaya
}

\section{Doi: $10.1515 / \mathrm{mjss}-2017-0047$}

\begin{abstract}
The collateral law is a provision and rule of law governing the legal relationship between the receiver and the receivable of credit by charging a guarantee. Then in about the loading of Flats with Rescue Rights. Therefore, based on the provisions of Article 27 on mortgage law, the Flats are no longer possible guaranteed by Mortgage and Fiduciary, since the object of collateral with Mortgage and Fiduciary in flats act has become the object of collateral which is burdened with mortgage right by mortgage law. The Right to Land in the Flats can not be burdened with the mortgage right, because it is a collective land, it is only possible to be guaranteed with the Mortgage right only by the Developer at the time of building the flats, but when it was established the flats, it is no longer possible Burdened with a mortgage, which may be just the Property of the Housing Unit because it is the possession of a person who is the things that stand on the ground together.
\end{abstract}

Keywords: flat, collateral law, Indonesian Housing Law, Mortgage law

\section{Introduction}

Flats or Apartments has become one of the Indonesian fastest growing industries. Flats are multilevel buildings constructed in an environment divided into functionally structured sections, both horizontally or vertically where each unit can be owned and used separately, especially for shelter equipped With shared parts, common objects, and common ground.

The Flat sector provides effects in various fields, namely by encouraging a series of other economic sectors. All economic activities both in the field of services and goods will basically always need the product Flats/Apartments as one of the factors of production. For example, banking services that provide financial services also still require the existence of Flats/Apartment products act as a place or means to conduct transactions. Similarly, production or trade activities, as well as plantations/farms, will always need the Flats as the activities tool. Thus, the demand for flat products will continue to increase in line with the development of economic activities.

Borrow-lend activities have been conducted for a long time in social activities. As matter of fact, almost all communities make borrow-lend activities as an indispensable thing to support their economic development activities. Related to this, various financial institutions, especially banks have helped fulfill the need for funds toward economic activities by providing loan money in the form of bank credit (Purbandari, 2013, 89). However, Bank will only grant the loan application submitted by the customer if there is any confidence in the certainty that the debtor can refund the credit. Therefore, in the banking credit activities, it is required to provide debt guaranteed by the debtor to the lender (creditor) in this case is the bank. The provision to grant the guarantee is in line with the general guarantees principle as stipulated in article 1131 of the Civil Code, that the debtor's property is entirely a guarantee of his debt.

Basically, the guarantee used by the debtor can be used immaterial or material assurance, 
which constitutes an immaterial guarantee is a guarantee which creates a direct relationship to a specific individual and can only be maintained by a particular debtor such as an individual guarantee (borgtoch). While the material guarantee is a guarantee in the form of absolute right of an object that has characteristics and direct relationship with the debtor in the form of moving and immovable objects.

In banking practice, not all types of goods or objects can be accepted toward credit activities. Some banks require strictly the type of credit guarantee object. The policy is based on certain reasons with due regard to its importance, namely the ease of binding, the certainty of the value (price), the ease of liquefaction, ease of supervision and maintenance. Therefore, the bank prefers the guarantee of material goods both Movable and immovable. This is because the assurance of material possessing material characteristics in the sense of giving the right to precede over certain objects and have the attached properties and follow the object in question. (Salim, 2007: 23)

Material assurance which according to Sri Soedewi Masjoen Sofyan (1981, 46-47) is called material assurance is: Guarantees with the absolute right over an object having characteristics of having a direct connection to a particular object, can be maintained toward anyone, always following the object and can be transferred. accordance with the assurance of material in banking activities, the object becomes the guarantee of the material is more widespread. The current evolving object that can be the object of collateral is flat. Flats are built to respond the developments that occur mainly in urban areas, where the level of housing demand is quite high while limited land does not allow the construction of homes in a leased house, so housing development is directed to the development of flats or apartments that embrace the concept of ownership of flats unit, Flats unit whose main purpose is used separately with main function as shelter and has a means of connecting to public road (Article 1 paragraph (3) of Law No. 20/2011 on Flats, hereinafter referred to as Housing Law).

According to Article 47 paragraph (5) of the housing law, it is said, " Freehold Sarusan Title can be used as a debt guarantee with the burden of Mortgage right (HT) in accordance with the provisions of legislation". Dealing with this, the flat/apartment units can be used as collateral for credit guarantee. That in this case, the object of credit guarantee and tied up with the Mortgage Right is not the land but the property rights of the apartment unit as well as the joint object of the ownership the apartment unit. (Ari S, 2007: 27)

Based on the mentioned above matter, the author is interested to analyze the development of the guarantee law regarding flats in Indonesia. The object of his study focuses on the concept of guarantee provision forced based on Indonesian law. Thus this research problem conducted on this study focused on:

A. Legal Collateral In the Civil Code and beyond the Civil Code

B. Flats and Properties of Housing Unit As Credit Collateral

The purpose of this study is to discuss theoretically flats as collateral for credit. So specifically this study aims to know, analyze, and describe the unit of flats as a credit guarantee and to know, analyze and illustrate the way of imposition of collateral for apartment units.

\subsection{Research Method}

Research is a fundamental tool in the development of science. Research has the purpose of expressing the truth systematically, methodologically, and consistently, including research of law. As the science of Sui Generis, meaning the law of science is a science of its own type, the science of law has a character that is characteristic normative nature (Hadjon, 2005: 1). Thus the method of research in the science of law also has its own method. The methods and procedures of research in the natural sciences and the social sciences can not be applied in the science of law. (Marzuki, 2006: 26)

The Type of this research is normative juridical with normative legal research methods, namely review and analyze legal materials and legal issues related to the problems studied. This research is done to solve the problems that arise, while the results to be achieved is a prescription of what should be done to overcome the problem.

The approach used in this research are the statute approach, historical approach, and 
conceptual approach. The historical approach allows researchers to understand the law more deeply about a system or institution or a particular legal provision, it was done to minimize the error, both in the understanding and application of a particular institution or legal provisions. The current legal system contains elements of the legal order and forms the shoots of future law.

The statute approach is conducted by reviewing all laws and regulations relevant to the legal issues being addressed. The law approach will open up opportunities for researchers to study the consistency and appropriateness of a law with other laws or between the law and the Constitution of the State of the Republic of Indonesia Year 1945 or between the regulation and the law of land. (Marzuki, 2006:93)

Furthermore, the legal materials Sources used in this study is Primary Legal Material, that is an authoritative legal material, meaning that the legal material has the authority, which consists of legislation, official records or treatises.

In addition, This study also used the legislation as the primary legal material, namely the Civil law Code, Law No. 4/1996 on the Rights of Dependence on Land and Materials related to the Land (mortgage law), Law No. 42/1999 on the Fiduciary and Law No. 20/2011. Whereas, the Secondary legal materials covering all publications about laws that are not official documents. Publications on this law include textbooks, theses, dissertations of law, dictionaries of law, comments on court decisions as well as legal opinions from experts published through journals, magazines or the internet.

\section{Results and Discussion}

\subsection{Legal Collateral In the Civil Code and beyond the Civil Code}

The provisions of collateral contained in the Book of Civil code Book II of Objects and Book III on the binding. General assurance derived from the term of law (Sofwan, 1980: 43-46), namely the Civil Code which the rule reads: "All the materiality of the owed, both movable and immovable, both existing and new will exist later on, Be liable for all personal binding (Article 1131), in the provisions of Article 1132, it is determined that the material is collateral for all persons who owe it; The sales revenue of the items is divided according to its equilibrium, namely, according to the size of the respective receivables, except where among the debts there are legitimate reasons for precedence. And special Guarantee based on the binding, ie mortgage, pledge, Fiducia, and staging or personal guarantee.

Some of the Collateral in the Civil Code are no longer used or unbound. Some of them are subject to and bound by the Commercial Code (KUHD), the Laws and Regulations, such as: The dependent right, regulated in Law No. 4/1996 on the mortgage law of Land and Property Rights (UU HT), Mortgage is regulated in Article 314 of the KUHD, Act Number 2/1992 on Shipping as well as government regulation No. 23/1985 for Mortgage and in Article 12 of Law No. 15/1992 on Aviation for Aircraft Mortgage, Pawn, Set forth in Article 1150-1160 on Civil Code, Fiduciary, regulated in Law No. 42/1999 on collateral of Fiduciary.

Law No. 9 Year 2011 on Amendment to Law No.9 Year 2006 on Warehouse Receipt System and other Laws and Regulations related to collateral such as general suspension guarantee to corporate guarantee.

\subsubsection{Fiduciary}

Fiduciary by word of origin comes from the word "fides" which means belief. In accordance with the meaning of this word, the relationship (Law) between the debtor (fiduciary giver) and the creditor (fiduciary recipient) is a trust-based legal relationship (Widjaja,2000:13). The fiduciary giver believes that the fiduciary recipient is willing to return the property rights that have been handed over, upon payment of the debts. In addition, Widjaja $(2000,113)$ states that the fiduciary recipient believes the fiduciary giver will not abuse the security goods under his control.

Based on Article 1 of Law No. 42 of 1999 on Fiduciary Guarantee, contained the definition or limitation of Fiduciary and Fiduciary Guarantee. Article 1 point 1 of the Fiduciary Guaranty Act No. 
42 of 1999 states: The definition of fiduciary is the transfer of ownership rights of an object on the basis of trust with the provision that objects whose ownership rights are transferred remain in the possession of the object owner. Dealing with this definition, Satrio (2002: 159) grouped 3 fiduciary characteristics as below:

a) Transfer of an object ownership;

b) On the basis of trust;

c) It remains in the possession of the object owner

Guarantees in the form of fiduciary, as stipulated in Law No.42 of 1999 on Fiduciary. states Fiduciary is one form of guarantee where the objects guaranteed by the debtor to the creditor for the repayment of the debts are in the hands of the debtor. Thus the debtor surrenders property rights to his/her own moving goods to the creditor, provided that the goods remain in the hands of the debtor.

\subsubsection{Mortgage Right}

Mortgage Right $(\mathrm{HT})$ is a security right imposed on Land Rights, as referred to in Law No. 5 Year 1960 on Basic Agrarian Principles (UUPA), Mortgage Right is one of the institutions of material security right which is born from one agreement. Namely, a credit agreement which is a common agreement made in the field of the banking law, in the credit agreement there are two parties involved that are the bank as creditor and customer as the debtor. In the credit agreement is usually included also a guarantee of material to guarantee debt repayment debtors. The material guarantee must be made in an agreement that has material rights and it is an accesoir (additional). One of the guarantees with material rights is the Mortgage Right. Soedewi, 1975: 6)

Object Classification of Mortgage Right can be viewed from different angles depending on the further development of the statutory regulations governing mortgages. (Article 4 paragraph 1 on mortgages law) then that could be the object of Mortgage Right is only: right of ownership (Article 25 UUPA, Right of Business (Article 33 UUPA), Right to Build (Article 39 UUPA) Then if In terms of those designated by the Mortgage law (UU HT) Article 4, paragraph 2, one can add another type of Mortgage Right is the Right to Use on state land which according to the applicable provisions shall be registered and by its nature transferable, while in the development of the Mortgage right as referred to by the Law No. 20 of 2011 on Flats (Article 27 UU HT) states that there are additional objects of Mortgage Rights that are Styles which stand on the land of right of ownership, Building rights, and Right to Use given by the State as well as the Ownership of the Housing Unit (HMSRS) Whose the buildings are established on the land of right of ownership, Building rights, and Right to Use provided by the State.

Dealing with the material assurance in banking activities, then the object becomes the collateral of the material is more widespread. The current evolving object that can be the object of collateral is the flats built to respond to growth occurring especially in urban areas.

\subsection{Flats and Properties of Housing Unit As Credit Collateral}

The term collateral is a translation of the Dutch language, namely Zekerheid or Cautie. Zekerheid or cautie covers in general the ways in which creditor guarantees the fulfillment of its claims, in addition to the general debtor's liability to his goods. (Salim, 2008: 21)

According to Mariam Darus $(1991 ; 32)$, the credit agreement is the "Preliminary Agreement" (Voorovereenkomst) of the money transfer, this is the result of an agreement between the giver and the borrower regarding the legal relations between them. In the law of collateral which is an additional agreement or accessory is always preceded by a credit agreement. So there is no collateral without credit agreement.

Article 47 paragraph (5) On the housing law (UURS) states, " Freehold Title of Sarusun can be used as debt collateral with the burden of Mortgage right in accordance with the provisions of law and regulation." Under this provision, Property right of flat units (HMSRS) can be used as credit collateral with the burden of Mortgage. This provision is in line with the UU HT and as the implementation of Article 51 on UUPA. Article 27 of UU HT stipulates that "This UU HT's provision 
applies to the imposition of guaranteed rights on Flats and Property right of flat units". So that, following the flats can be used as credit guarantees it was arranged in a limitation by mortgage law.

The granting of Mortgage right at the Property right of flat units comprise of certain Stages of which they are part of the juridical and administrative process.

\subsubsection{Credit Agreement}

The credit agreement is a basic agreement which served as the first document or as an initial document to prove the existence of a debt agreement. Based on Article 10 paragraph (1) on mortgage law which reads:

"The granting Mortgage right is preceded by a pledge to grant the Deposit Rights as a guarantee of certain debt repayment, poured in and indispensable part of the agreement of the respective debts or other agreements that incur such debt".

The Mortgage Rights Agreement is an accessory with a principal agreement. one Mortgage Rights can not stand alone, but it is a subset of the principal agreement.

\subsubsection{Establishment of Deed of Giving mortgage right}

the process of making the Deed of Giving mortgage right (APHT) by an land titles registrar (PPAT) under Article $11 \mathrm{UU}$ HT shall include the name and identity of the mortgage right holder and owner, the domicile of the parties, the clear appointment of the guaranteed debt, the value of the dependents, and the description of the object of the Mortgage's right This apartment unit that will be used as a debt guarantee.

Whereas in a material agreement, it basically has a character that is sustainable (Voortdurende Overeenkomst) which begins with the grant agreement of HT and ends at the time of registration. As long as the registration has not been made, this agreement is not a material agreement. (Darus, 1991: 61),. The next action taken by the Land Office is to return the land certificate containing the note of granting the Mortgage Right to the holder of the land right and simultaneously giving the Certificate of the Deposit Rights to the creditor.

The legal deeds related to Sarusun are always connected to the land where the apartment building is established or built. So as a result of the flats is inseparable from the land, the starting point of its arrangement is based on the National Land Law and this is a logical consequence of the unification of the Land Law since September 24, 1960, where all the provisions of Book II of the Civil Code along the governing the earth, water, and natural resources Contained therein shall be declared no longer valid except in regard to mortgages. (Sutedi, 2006: 19)

Therefore, based on the provisions of Article 27 on UU HT, it can be concluded that, After the entry into force of mortgage law, Flats are no longer possible secured by Mortgage and Fiduciary, Because the object of collateral with Mortgage and Fiduciary in housing law has become the object of collateral in burdened with mortgage right By mortgage law. The Right to Land in a Flats can not be burdened with mortgage rights, because it is a collective land which is a collective property, it is possible to be guaranteed by the Mortgage Right only by the Developer at the time of building the flats, but when it has been established its apartment can no longer be burdened With a mortgage right, which may be just the Property of the Housing Unit because it is the possession of a person who is the things that stand on the common ground.

Referring to the provisions of mortgage law and the Fiduciary Guarantee law, the burden of flats as collateral for credit is tied to the Guaranteed Right, which is the object of Mortgage Right is not the land but the property rights of the unit of the flats which therefore in addition to the respective apartment units are also part of the joint, Common objects, and joint land equal to the ownership of the flat units. (Hutagaluh, 2007: 70)

The imposition of HMSRS as credit guarantee is based on a credit agreement, in which a security agreement is a bond between a creditor and a debtor or a third party guaranteeing the repayment of the debt arising from the granting of the loan. The credit guarantee agreement is an 
accessory agreement, which is always an agreement associated with the principal agreement.

If the debtor breaches the pledge in the credit agreement, then the Deposit Rights will be executed in accordance with the provisions of Article $20 \mathrm{UU}$ HT, where the object of Mortgage Rights is sold through a public tender in the manner specified in the prevailing laws and regulations and the holder of the Mortgage Right shall be entitled to take all or part of the proceeds The settlement of the receivables, with the right which precedes other creditors' creditors which can be executed in two ways:

a) Based on the provisions of Article 6 of the HT Law, namely the right of the first Depositary to sell the object of Mortgage Right to their own power reinforced by the promise referred to in Article 11 paragraph 2 e of Law No. 4 of 1996 on the mortgage law (UU HT) or also known as parate execution.

b) Based on the Executorial Title contained in the Mortgage Right certificate as referred to in Article 14 paragraph $2 \mathrm{UU} \mathrm{HT}$, where states the execution is done by requesting court assistance or called by Fiat Execution.

\section{Conclusion}

Indonesian collateral Law originally stipulated in the Civil Code of Book II (law of objects), namely the material collateral like Pawn (Article 1150-1160 Civil Code) and Mortgage (Article 1162-1232 Civil Code) and Personal collateral (personlijk). In its development has been regulated outside the Civil Code and subject to the legislation on guarantees such as Law No. 4 of 1996 on the mortgage of Land and Property Affairs (UU HT) and Law No. 42 of 1999 on Fiduciary And other laws and regulations that impose warranties in any legal action such as credit agreements of banks and securities.

Article 47 paragraph (5) of the housing law states, "freehold title of sarusun can be used as debt guarantee with the burden of Mortgage right in accordance with the provisions of law and regulation." Under this provision, HMSRS can be used as credit guarantee with the burden of Mortgage. This provision is in line with the mortgage law, as implementation and Article 51 of UUPA. Article 27 of UU HT stipulates that "This UU HT provision applies to the imposition of guaranteed rights on Flats and HMSRS". So that can be used as flats/HMSRS as credit guarantees arranged in a limitation UU HT.

Therefore, based on the provisions of Article $27 \mathrm{UU} \mathrm{HT}$, it can be concluded that, After the entry into force of UU HT, Flats are no longer possible secured by Mortgage and Fiduciary, Because the object of collateral with Mortgage and Fiduciary in UURS has become the object of collateral in burdened with HT By UU HT. The Right to Land in a Flats can not be burdened with mortgage rights, because it is a collective land which is a collective property, it is possible to be guaranteed by the Mortgage Right only by the Developer at the time of building the flats, but when it has been established its apartment can no longer be burdened With a mortgage right, which may be just the Property of the Housing Unit because it is the possession of a person who is the things that stand on the common ground.

\section{References}

Purbandari. (2013). Hak Milik Atas Satuan Rumah Susun Sebagai Jaminan Kredit. Lex Jurnalica 10, 3. P. 89205.

Salim, H. (2007). Perkembangan Hukum Jaminan di Indonesia. Jakarta: Raja Grafindo Persada.

Sofyan, Sri Soedewi Masjoen. (1981). Hukum Perdata: Hukum Benda. Liberty: Yogyakarta.

Hutagaluh, Ari S. (2007). Kondominium dan Permasalahannya.: Revised edition. Depok: Badan Penerbit Fakultas Hukum Universitas Indonesia.

Hadjon, Philipus M and Tatik Sri Djatmiati. (2005). Argumentasi Hukum. Yogyakarta: Gajah Mada University Press.

Marzuki, Mahmud. (2006). Penelitian Hukum. Jakarta: Prenada Media.

Sofwan, Sri Soedewi Masjchoen. (1980). Hukum Jaminan di Indonesia, Pokok-pokok Hukum Jaminan dan Jaminan Perorangan. Yogyakarta: BPHN dan Liberty.

Widjaja, Gunawan and Ahmad Yani. (2000). Seri Hukum Bisnis Jaminan Fidusia. Jakarta: PT Grafindo Persada. 
J. Satrio. (2002). Hukum Jaminan, Hak-hak Jaminan Kebendaan. Bandung: PT. Citra Aditya Bakti. Masjehoen, Sri Soedewi. (1975). Hak Jaminan Atas Tanah. Yogyakarta : Liberty.

Salim, H. (2008). Perkembangan Hukum Jaminan Di Indonesia. Jakarta: Rajawali Pers.

Badrulzaman, Mariam Darus. (1991). Perjanjian Kredit Bank, , Bandung: PT. Citra Aditya Bakti.

Sutedi, Adrian. (2006). Implikasi Hak Tanggungan Terhadap Pemberian Kredit Oleh Bank dan Penyelesaian Kredit Bermasalah. Jakarta : BP. Cipta Jaya.

\section{Indonesian Regulation of law}

Law No. 20/2011 on Housing Flat law

Law No. 4/1996 on mortgage Right and Land-Related Objects.

Law No. 5/1960 on Basic Agrarian law.

Law No. 1/2011 on On Housing and Settlement Area.

Law No. 42/1999 on Fiduciary Guarantee 